CASE REPORT

\title{
Exophthalmos due to odontogenic intraorbital abscess in Cebus apella
}

\author{
Arianne P. Oriá ${ }^{1}$, Melissa H. Pinna ${ }^{1}$, Alessandra Estrela-Lima ${ }^{1}$, Deusdete G. Junior ${ }^{2}$, Fernanda A. \\ Libório $^{1,3}$, Francisco de Assis Dórea Neto ${ }^{4}$, Alberto V. D. Oliveira ${ }^{5}$, Marcos Nogueira ${ }^{6}$ \& Katia \\ Requião ${ }^{6}$
}

1 School of Veterinary Medicine and Zootechny, Federal University of Bahia, UFBA, Salvador, BA, Brazil

2 Faculdade de Ciências Agrarias e Veterinárias, Universidade Estadual Paulista, UNESP, Jaboticabal, SP, Brazil

3 Screening Center for Wild Animals (CETAS), Salvador, BA, Brazil

4 Metropolitan Union for Education and Culture (UNIME), Lauro de Freitas, BA, Brazil

5 Getúlio Vargas Zoobotanic Park, Salvador, BA, Brazil

6 Private Practice, Salvador, BA, Brazil

\author{
Keywords \\ enucleation - exenteration - primate

\section{Correspondence} \\ Arianne P. Oriá, Department of Pathology \\ and Clinic, Escola Medicina Veterinária e \\ Zootecnia, Universidade Federal da Bahia \\ (UFBA), Avenida Adhemar de Barros, \\ 500 - Ondina, CEP: 40170-110 Salvador, \\ BA, Brazil. \\ Tel.: +55 7132836749 ; \\ fax: +55 7132836718 ; \\ e-mail: arianneoria@ufba.br
}

Accepted December 17, 2012.

\section{Introduction}

In humans and animals, the displacement of the eyeball may occur by intraorbital abscess of odontogenic origin, which is rare and usually related to ascending infection coming from the maxillary molars $[1,2]$. This is due to the anatomical location of the tooth roots, and depending on the microorganism involved, enables a rapid infiltration of oral pathogens on adjacent sites [10].

The objective of this article is to report an odontogenic abscess leading to exophthalmos in a male Cebus apella, which to the authors' knowledge has not been published before in a non-human primate.

\section{Case report}

\section{History}

A male C. apella housed at the Screening Center for Wild animals was removed from the collective enclo- sure exhibiting weight loss, periorbital edema, exophthalmos of the right eye, and ipsilateral purulent nasal secretion. He was first treated by the local veterinary staff with ketoprofen $(5 \mathrm{mg} / \mathrm{kg}$, s.c. [s.i.d.], Ketofen $^{\circledR}$; Merial Animal Health, São Paulo, Brazil) and enrofloxacin (5 mg/kg, s.c. [b.i.d.], Flotril ${ }^{\circledR}$; Schering-Plough Animal Health, Whitehouse Station, NJ, USA). Three days after starting the treatment plan, the clinical symptoms got worse and the animal was referred for examination by the Ophthalmology Service at the Federal University of Bahia.

All protocols were in accordance with the Authorization and Information System on Biodiversity of the Ministry of Environment of Brazil (process no 27489-1). In addition, all procedures were conducted in accordance with the humane principles set forth in the ARVO Statement for the Use of Animals in Ophthalmic and Vision Research. 


\section{Clinical examination}

It was reported that the animal had selective and decreased appetite. It was observed that all canine teeth were fractured in the root region with pulp exposure, an orbital swelling was noted and also a mass of firm consistency with severe exophthalmos, lagophthalmia, pain upon palpation, and discomfort (the animal scratched the affected eye incessantly, with the thumb and index finger in an attempt to remove the secretions, licking his fingers afterward), chemosis, conjunctival hyperemia, dryness of the cornea surface, lack of eye mobility, absent pupillary reflex, and negative menace response; fluorescein staining of the cornea was positive. No abnormalities were detected on the left eye (Fig. 1A).

\section{Investigations}

A complete blood count, aspiration cytology, dental radiographs, and a computed tomography (CT) were conducted as a diagnostic plan.

After weighing $(3.2 \mathrm{~kg})$, general anesthesia was induced $(5 \mathrm{mg} / \mathrm{kg}$, i.m.) with tiletamine and zolazepam (Zoletil ${ }^{\circledR}$; Virbac Industry and Trade of Brazil, São Paulo, Brazil) and maintained with isoflurane (Isoforine ${ }^{\circledR}$; Cristália Chemicals Pharmaceuticals, Itapira, Brazil) diluted in oxygen. Dental radiographs, CT (Asteion $^{\mathrm{tm}}$ Super 4 Edition; Semp Toshiba, São Paulo,
Brazil), and aspiration cytology were followed. A decision to change from enrofloxacin to azithromycin $\left(40 \mathrm{mg} / \mathrm{kg}\right.$, s.c. [b.i.d.], Zitromax ${ }^{\circledR}$; Pfizer Laboratories, São Paulo, Brazil) for 10 days was made, due to broader antibacterial action.

The blood tests showed anemia and leukocytosis [9]. The X-ray images suggested a periodontal abscess in the upper right canine tooth, and the CT images also identified the presence of a firm consistent content in the retrobulbar region and in the maxillary sinus (Fig. 1B,C). Cytology revealed an inflammatory process. Due to the intense discomfort manifested by the animal, poor clinical condition, and the laboratory and image examination findings, a decision to perform initially an orbital exenteration was made.

\section{First surgical procedure}

The same anesthetic protocol utilized to carry out the tests, 1 day before, was accomplished. The periorbital region was prepared for aseptic surgery [8], and a subconjunctival enucleation was followed by the orbital cavity curettage. A friable tissue that appeared infected was noted, and then a sterile swab was used to collect a sample for culture. The globe and the orbital contents were fixed in $10 \%$ neutral buffered formalin and submitted for gross and histopathologic evaluation. There were several reasons why we chose to perform
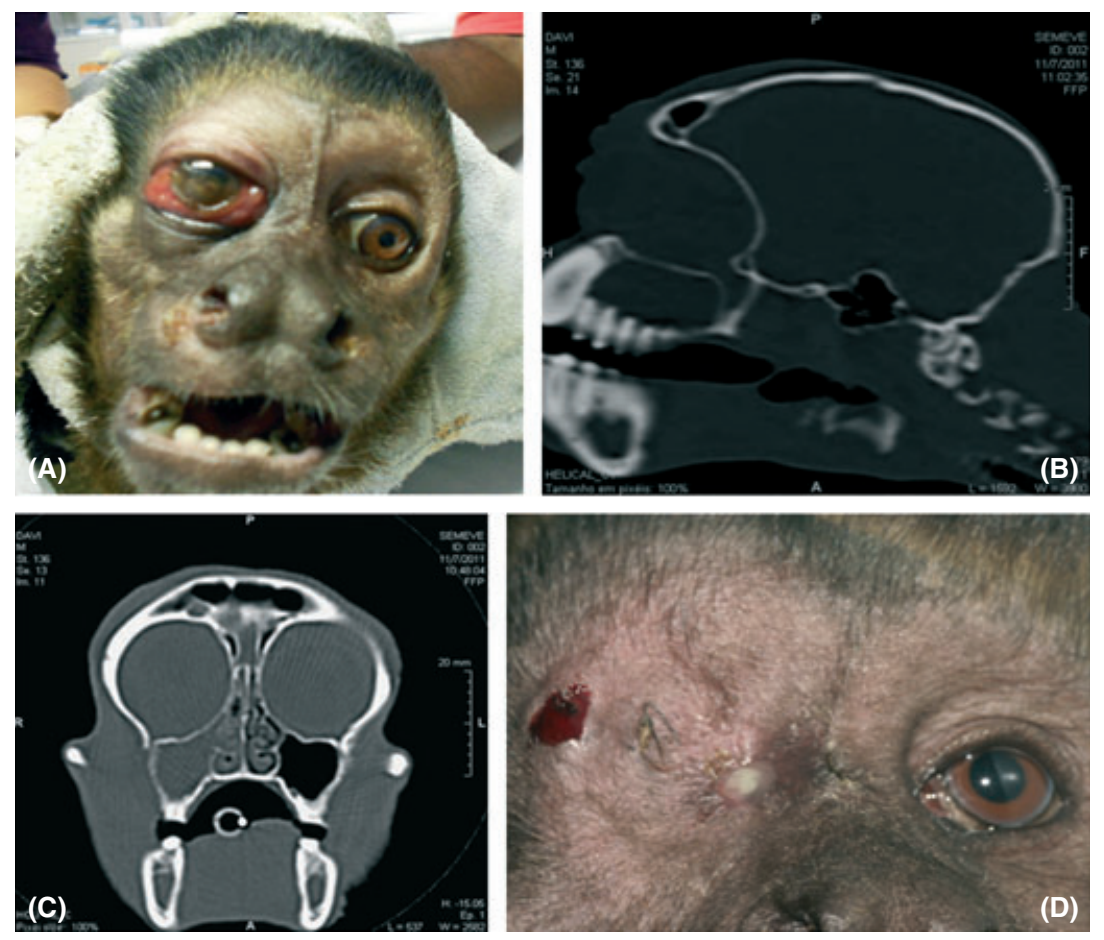

Fig. 1 (A) Exophthalmos and intense chemosis in the right eye. (B) CT image showing an abscess in the root of the canine tooth. (C) CT image. Note radiodensity similar to water in the right maxillary sinus. (D) Mucopurulent secretion in the right medial orbit. 
the exenteration at first with subsequent dental treatment: the procedure was performed on an emergency basis due to an imminent eye perforation, the availability of suitable instruments and skilled professionals, and the animal clinical status. This was reaffirmed by anesthetic complications (apnea and premature ventricular complexes) that the animal presented during surgery.

A single injection of fentanyl citrate $(0.02 \mu \mathrm{g} / \mathrm{kg}$, i.v., Fentanila $^{\circledR}$; Pharmaceutical Hipolabor, Santa Luzia, Brazil) was administered immediately after surgery. A 5-day course of systemic dipyrone $(25 \mathrm{mg} / \mathrm{kg}$. p.o. [t.i. d.], sodium dipirona ${ }^{\circledR}$; German lab, Anápolis, Brazil) and tramadol HCL (2 mg/kg, s.c., [t.i.d.], Tramal ${ }^{\circledR}$; Pfizer Laboratories) and a 3-day course of systemic ketoprofen $\left(5 \mathrm{mg} / \mathrm{kg}\right.$, s.c., [s.i.d.], Ketofen ${ }^{\circledR}$; Merial Animal Health) were dispensed. The azithromycin was kept until the culture results.

\section{Follow-up}

One day following surgery, the patient showed clinical improvement with increased appetite and without any signs of discomfort. Ten days after, with the culture results (Table 1), a 21-day course of systemic gentamicin (4 mg/kg, s.c., [b.i.d.], Garamicina ${ }^{\circledR}$; Schering-Plough Animal Health) was given.

Twelve days after surgery, the sutures were removed and a mucopurulent secretion originating from the right nasal cavity and ipsilateral medial canthus were observed (Fig 1D). Recheck of blood count showed a decrease but persistent leukocytosis and a less pronounced anemia [9]. The histologic examination

Table 1 Results of culture and antibiogram

\begin{tabular}{|c|c|c|}
\hline Sample & Culture & Antibiogram - Sensitivity \\
\hline \multicolumn{3}{|l|}{ Before surgery } \\
\hline Right nasal cavity & $\begin{array}{l}\text { Proteus sp. } \\
\text { Staphylococcus sp. } \\
\text { Escherichia coli } \\
\text { Diphteroides }\end{array}$ & Gentamicin, Polymyxin B \\
\hline \multicolumn{3}{|l|}{ After surgery } \\
\hline $\begin{array}{l}\text { Secretion of } \\
\text { the orbital cavity }\end{array}$ & $\begin{array}{l}\text { Proteus sp. } \\
\text { Streptococcus } \\
\text { beta-hemolytic } \\
\text { Staphylococcus sp. } \\
\text { Escherichia coli }\end{array}$ & $\begin{array}{l}\text { Amicacine, Gentamicin, } \\
\text { Tobramycin }\end{array}$ \\
\hline $\begin{array}{l}\text { Swab the } \\
\text { tooth socket }\end{array}$ & $\begin{array}{l}\text { Proteus sp. } \\
\text { Streptococcus } \\
\text { beta-hemolytic } \\
\text { Staphylococcus sp. } \\
\text { Escherichia coli } \\
\text { Difteróides }\end{array}$ & Gentamicin \\
\hline
\end{tabular}

J Med Primatol 42 (2013) 101-104

(C) 2013 John Wiley \& Sons A/S. Published by Blackwell Publishing Ltd revealed an acute suppurative myositis indicating a retrobulbar abscess.

\section{Second surgical procedure}

Thirty days after the first surgical procedure, the animal appeared alert, in a good condition with normal appetite and water consumption. However, a purulent secretion was still observed in the right medial canthus. The animal was anesthetized with the previously described protocol for the extraction of upper right canine. The material from the alveolar cavity was sent to culture. Gentamicin was extended for 21 days longer than the initial prescription and supported a total of 42 days.

\section{Discussion}

Several factors contribute to the late diagnosis of diseases which affect wild animals: their size, the amount in enclosures, the need for chemical restraint for examination, the lack of scientific knowledge (paucity of documented cases), and, above all, the adaptation to delay clinical manifestation of disease [5]. These difficulties were encountered, once the patient lived in broad and collective enclosure, which has hindered the early identification of pathological change. It should be noted that despite being calm, the animal was not docile, which complicated, but not hindered the pre-, trans-, and post-operative care. Leukocytosis, ipsilateral sinusitis, periorbital edema, chemosis, restricted eye movement, and blindness with severe exophthalmos are considered common changes found in retrobulbar abscesses [2, 3, 12].

The occurrence of Proteus sp. had already been reported as part of normal conjunctival flora in clinically healthy $C$. apella [6]. Still, the habit of rubbing the eyes with the hands could be a stereotypic behavior initiated by the stress of removal from their habitat, transportation, socialization with humans may have favored the growth of the above microorganisms [4]. Staphylococcus, Proteus, and beta-hemolytic Streptococcus have been described as microorganisms found in the retrobulbar abscesses [11].

There are three forms of ascending dental infection: hematogenous, lymphatic, and direct extension [1, 12]. Odontogenic orbital infection from an ipsilateral maxillary molar tooth was previously described in human patients [1, 10]; however, in this study, we believe the patient developed ascending bacterial migration from the upper canine tooth. It has been reported in the literature the possibility of rapid infiltration of pathogens at adjacent locations including the retrobulbar region [1, 10]. Culture identified beta-hemolytic Streptococcus 
which has virulence factors that could facilitate tissue infiltration. These virulent factors include hyaluronidase, which unfolds the hyaluronic acid promoting connective tissue disorganization and allowing bacterial dissemination; fibrinolysin, a proteolytic enzyme that dissolves blood clots and breaks the plasminogen into plasmin, degrades fibrin and promotes the escape from local immune mechanisms; and hemolysins, which cause erythrocyte lysis and may influence the anemic process [7]. X-ray and CT imaging demonstrated linkage from the canine tooth root to the retrobulbar region, and ocular secretion was observed during tooth manipulation.
For these reasons, it is believed that this case was a retrobulbar abscess of odontogenic origin.

The measures adopted were sufficient for the resolution of the disease process. The vital functions of the patient's body were normal, and the patient was reinstated to the group, which behaved in a manner common to his kind.

\section{Acknowledgments}

The authors acknowledge Prof. Luis Fernando Pita Gondim and Prof. Marta Vasconcelos Bittencourt.

\section{References}

1 Allan BP, Egbert MA, Myall RWT: Orbital abscess of odontogenic origin. Case report and review of the literature. J Maxillofac Oral Surg 1991; 20:68-270.

2 Barnett KC, Crispin SM: Globe and orbit. In: Feline ophthalmology. 4th edn. Barnett \& Crispin (eds.) Philadelphia, PA: Elsevier, 2005; 37-8.

3 Bullock JD, Fleishman JA: The spread of odontogenic infections to the orbit: diagnosis and managemet. J Maxillofac Oral Surg 1985; 43:749-55.

4 Cleff MB, Soares MP, Madrid IM, Meinerz ARM, Xavier MO, Albano APN, Fonseca AO, Silveira E, Meireles MCA: Candidíase cutânea em Cebus apella (macaco-prego). Ci Anim Bras 2008; 3:791-5.

5 Fecchio RS, Rossi JL Jr, Ferro DG, Giosso MA: Medicina preven- tiva aplicada à odontologia em animais selvagens. Nosso Clínico 2009; 12:44-52.

6 Galera PD, Ávila MO, Ribeiro CR, Dos Santos FV: Estudo da microbiota da conjuntiva ocular de macacos-prego (Cebus apella - linnaeus, 1758) e macacos bugio (Alouatta caraya - humboldt, 1812), provenientes do reservatório de Manso, MT, Brasil. Braz J Vet Res Anim Sci 2003; 40:83-9.

7 Koneman EW, Allen SD, Janda WM, Schreckenberger PC, Winn WC Jr: Cocos Gram-positivos. In: Diagnóstico microbiológico. 5th edn. Koneman, Allen, Janda, Schreckenberger \& Winn Jr (eds.) Rio de Janeiro: Editora Médica e Científica Ltda, 2001; 589-98.

8 Oliveira PM, Pinna MH, Oriá AP, Martins Filho EM, Laborda SS, Pithon PSB, Gomes Junior DC,
Costa Neto JM: Polivinilpirrolidona-iodo (PVP-I) em base aquosa na antissepsia de campo operatório oftálmico de cães. Rev Bras Saúde Prod Anim 2010; 11:1095-104.

9 Riviello MC, Wirz A: Haematology and blood chemistry of Cebus apella in relation to sex and age. $J$ Med Primatol 2001; 30:308-12.

10 Stübinger S, Leiggener C, Sader R, Kunz C: Intraorbital abscess a rare complication after maxillary molar extraction. J Am Dent Assoc 2005; 136:921-5.

11 Suneetha N, Battu RR, Thomas RK, Bosco A: Orbital abscess: management and outcome. Indian $J$ Ophthalmol 2000; 48:129-34.

12 Yates C, Monks A: Orbital cellulitis complicating the extraction of infected teeth. J Dent 1978; 3:229-32. 